Article

\title{
Sustainability Reporting and Firm Value: Evidence from Singapore-Listed Companies
}

\author{
Lawrence Loh ${ }^{1, *}$, Thomas Thomas ${ }^{2}$ and Yu Wang ${ }^{3}$ \\ 1 Department of Strategy and Policy, NUS Business School, National University of Singapore, 15 Kent Ridge \\ Drive, Singapore 119245, Singapore \\ 2 ASEAN CSR Network, \#08-03 Keppel Towers, 10 Hoe Chiang Road, Singapore 089315, Singapore; \\ thomas@asean-csr-network.org \\ 3 Centre for Governance, Institutions and Organisations, NUS Business School, National University of \\ Singapore,1 Business Link, Singapore 117592, Singapore; wang0803@e.ntu.edu.sg \\ * Correspondence: bizlohyk@nus.edu.sg
}

Received: 22 September 2017; Accepted: 13 November 2017; Published: 17 November 2017

\begin{abstract}
As sustainability reporting has emerged as one of the most critical issues in the business world, this research aims to investigate the relationship between sustainability reporting and firm value based on listed companies in Singapore. We use an established sustainability reporting assessment framework and test how both the adoption and quality of sustainability reporting are related to a firm's market value. Empirical results suggest that sustainability reporting is positively related to firm's market value and this relationship is independent of sector or firm status such as government-linked companies and family businesses.
\end{abstract}

Keywords: sustainability; sustainability reporting; firm value

\section{Introduction}

Non-financial corporate performance has begun to capture the attention of increasing number of investment professionals as they realize that profitability alone is not sufficient for a firm's long-term growth. By looking beyond economic, strategic and operational factors to include environmental and social considerations, sustainability reporting helps boost corporate transparency, strengthen risk management, promote stakeholder engagement and improve communications with stakeholders [1]. Firms are commonly assumed to pursue profit maximization while such non-financial disclosure seems to be costly. However, researchers have shown that there is a linkage between sustainability disclosure and firm value [2]. Most of the studies are specifically concerned with the more advanced and mature economies. For Asia, especially Singapore, we have moved beyond Khaveh, Nikhasemi, Haque and Yousefi's [3] paper, which was an early study drawn from a limited sample of selected industries based on a primarily disclosure assessment driven by corporate social responsibility (CSR). Our study adopts a more holistic measurement of sustainability based on a more representative sample of all mainboard-listed companies on the Singapore Exchange (SGX).

In the study, we utilize the well-known practice tool, Global Reporting Initiative (GRI), as it provides a common ground for sustainability reporting and has been very successful in terms of the adoption rate, comprehensiveness, prestige, and visibility [4,5]. It is not a theoretical framework in itself, although it has been used extensively by companies. Following GRI guidelines, sustainability reporting refers to the disclosure of following four main aspects, economic, environmental, social and governance, in a strategic manner. Sustainability in the current form is a broader concept, and shall not be taken as equivalent as CSR alone. However, sustainability reporting is often associated with other terms for non-financial reporting such as "CSR" reporting or "triple bottom line" reporting. 
It is worth noting that there has been a proliferation of reporting regulations that incentivize companies to improve their sustainability disclosure [6]. For example, sustainability reporting will be changed from voluntary to reporting on "comply or explain" basis in Singapore, which signifies that increasing attention will be paid on sustainability for Singapore listed companies [1].

As sustainability reporting is a relatively new topic in Asia, only a limited number of studies have been done in the region, especially the key business hub of Singapore. Our paper is among the pioneers that has studied sustainability and linked its disclosure to firm value, which helps validate the sustainability reporting policies in Singapore. In addition, our assessment framework of sustainability reporting is aligned with international guidelines and has taken local factors into consideration.

This paper examines the relationship between firms' sustainability reporting and market value. After the introduction section, this paper reviews existing literature on the relationship between sustainability reporting and firms' market value. Based on the literature, we discuss the theories and come out with the hypotheses. The next section explains the data and methodology, followed by the empirical results and analysis. In the last two parts, we highlight the contributions and limitations of this study, and then draw the conclusions.

\section{Literature Review}

The treatment of sustainability overlaps with that for CSR in the literature. While there is a conceptual distinction between the two terminologies in that sustainability is a broader notion, CSR is often addressed in conjunction with sustainability as it is a means to achieve this sustainability. In reality, the commonality exists essentially in the reporting practices and the CSR is often deemed an aspect of sustainability.

Scholars have started to pay attention to the potential linkage between sustainability reporting and market value for some time. For instance, Herremans, Akathaporn and Mclnnes [7] find that large U.S. manufacturing companies with better reputations for social responsibility outperformed companies with poorer reputations during the six-year period 1982-1987, and companies with higher profits tend to be more socially responsible, resulting in a steadier performance and lower total risk. With increasing awareness of corporate social responsibility, more research has been conducted. For example, Simpson and Kohers [8] find a positive relationship between CSR and financial performance, based on the sample of companies from banking industry and the use of Community Reinvestment Act ratings as the social performance measure. Later in 2003, Orlitzjy, Schmidt and Rynes [9] conducted a meta-analysis of 52 studies with a total sample size of 33,878 observations. They conclude that corporate social performance is positively correlated with corporate market value. In general, corporate virtue in the form of social and, to a lesser extent, environmental responsibility is rewarding.

As sustainability practices becomes more widely adopted by socially conscious corporations, the relationship between sustainability and firm value has also been explored by scholars in recent years. Using the Dow Jones Sustainability Index (DJSI), Clark and Allen [10] conclude that wealth maximization is associated with sustainability leadership. In addition, according to Ameer and Othman [11], significantly higher mean sales growth, return on assets, income before taxes and cash flows from operations in some sectors are discovered when companies engaged in sustainable practices compared to those who did not, based on data of the top 100 sustainable global companies in 2008. In addition, publishing a sustainability report is found to have positive effects on the firm's market value, which implies that investors attach a positive value to such reports and thus reflecting the anticipation of future cash flows [2].

Nevertheless, such positive relationship does not stand for other studies. For example, no direct relationship between share returns and social and environmental disclosure among UK companies is found [12]. A short-term negative impact of sustainability practices on firm performance is revealed in López, Garcia and Rodriguez's [13] analysis of two groups of 55 firms listed on the DJSI and Dow Jones Global Index (DJGI) from 1998 to 2004. Furthermore, the results of Cormier and Magnan's [14] paper are also contradictory. They find that environmental disclosure has a moderating impact on 
the stock market valuation of a German firm's earnings but does not significantly influence the stock market valuation of Canadian and French firms' earnings. In addition, Guidry and Patten [15] find that there is no significant market reaction to the announcement of the release of sustainability reports, but companies with the highest quality reports exhibited significantly more positive market reactions than companies issuing lower quality reports, and Carnevale, Mazzuca and Venturini [16] have not found strong evidence among European banks that social reporting is positively correlated with the market value of firms. In their cross-country analysis, only in some countries does social reporting contribute to a higher market value; in some others, this correlation is a negative one. In general, there is no universal conclusion on the relationship between sustainability reporting and firm value.

Meanwhile, other aspects have been explored as well. Some scholars study on the effect of financial crisis and conclude that CSR reporting and assurance may help companies differentiate their products or services from the competition and reinforce the trust from stakeholders, as results show that the number of CSR reports increases significantly with the crisis [17]. Some focus on the motivation. To name a few, Branco and Rodrigues [18] point out two main factors that motivate companies to publish CSR reports: good relations with stakeholders, and conforming to stakeholder norms on operations, and Souto [19] thinks that CSR offers confidence to stakeholders in terms of responsibility and trust.

In terms of a domestic context, findings from Khaveh et al.'s [3] study of Singaporean companies also reveal a positive and significant relationship between CSR disclosure and shareholder wealth.

\section{Theoretical Approach}

There are a number of existing theories on the relationship between sustainability disclosure and firms' market value.

In fact, unifying all empirical findings within one theoretical framework remains a challenge, so sustainability reporting is a complex phenomenon that cannot be explained by a single theory $[20,21]$. Among them, some of the most commonly seen include agency theory, signal theory and legitimacy theory.

According to agency theory, voluntary disclosure of firms, mainly on social and environmental aspects, is a means to reduce agency costs or future agency costs that may occur in the form of legislation and regulation [20,22]. This reduction in the costs will affect the risk profile and profitability of companies and thus affect the market value. Signal theory, in addition, suggests that companies that disclose on environmental issues send a signal that they are engaged in proactive environmental strategy as they are incentivized to inform shareholders and other stakeholders by voluntarily disclosing more $[23,24]$. Therefore, these positive signals make the companies more appealing to investors in the stock market. In the perspective of legitimacy theory, corporate social reporting provides information that legitimizes company's behavior with the aim to influence stakeholders' and eventually society's perceptions about the company $[25,26]$, resulting in a higher firm value. It has become one of the most cited theories when it comes to social and environmental accounting [27].

After considering the above theories, the following hypothesis is proposed for the relationship between making disclosure on sustainability and market value of companies:

Hypothesis $\mathbf{1}\left(\boldsymbol{H}_{\mathbf{1}}\right)$. Companies with sustainability reporting will have a higher market value than companies without sustainability reporting.

Other than reporting on the sustainability related issues, the quality of the report also matters. Many benefits from good CSR reporting within the broader related aspect of sustainability, such as attraction of better talent and motivation of employees, cannot be mimicked by poor CSR performers as the latter face obligations to incur future CSR expenditures with no incremental returns to shareholders, which implies that CSR disclosures increase firm value [28-31]. 
From the management's point of view, moreover, higher quality of disclosure contributes to the reduction of information asymmetry between managers and investors, as it reassures the investors on many an aspect of operations and performance, which, in turn, helps reduce the information costs incurred by investors [32]. Therefore, expanded disclosure serves as an incentive to minimize the firm's cost of capital, thus reducing the firm's cost of capital and increasing the stock liquidity as well as the valuation [33,34]. In addition, higher disclosure or better sustainability reporting improves the credibility of firms' profitability as it allows investors to make decisions with less risks and more efficiency $[14,35,36]$, which may suggest higher firm value.

As a result, we also examine the quality of the sustainability report on firm value and propose the following hypothesis:

Hypothesis $2\left(\mathbf{H}_{2}\right)$. Companies with more sustainability disclosure (higher quality of sustainability reporting) will have a higher market value than companies with less sustainability disclosure (lower quality of sustainability reporting).

\section{Data and Methodology}

\subsection{Sample Size and Sources of Data}

Our study covers companies listed on the SGX Mainboard. The total sample size is 502, amongst which delisted companies, suspended companies and secondary listings are excluded. Sources of the data include Bloomberg, Osiris and company disclosures.

For sustainability reporting and firm status, all information we consider is publicly available, of which major sources are the annual reports and sustainability reports or equivalents if applicable.

\subsection{Sustainability Reporting}

In this study, sustainability reporting refers to the disclosure of non-financial information, including aspects such as governance, economic, social and environmental. We take information disclosed by companies up to 31 December 2015 into account. Listed firms with annual reports published by the end of 2015 are covered in the study. Sustainability practices of companies disclosed on their corporate website, standalone sustainability report, and/or in the annual report are considered.

First, we analyze whether a company has reported sustainability, and then for those that do, we further evaluate the sustainability reporting level by generating a score using a measurement scheme developed by ASEAN CSR Network and Centre for Governance, Institutions and Organisations $[37,38]$. While this scheme is based on the GRI, it is not a conceptual framework but serves to operationalize the sustainability reporting construct. There are 23 criteria in the scheme, grouped into four indicators: Governance, Economic, Environmental and Social, as denoted in Table 1.

Table 1. Sustainability reporting measurement scheme.

\begin{tabular}{cccc}
\hline Governance & Economic & Environmental & Social \\
\hline Code of corporate governance & Economic value generated & Energy & Diversity and equal opportunity \\
\hline $\begin{array}{c}\text { Governance procedures } \\
\text { ethics }\end{array}$ & Value and supply chain & Water & Labour and industrial relations \\
\hline & $\begin{array}{c}\text { Investment in non-core business } \\
\text { infrastructure }\end{array}$ & Carbon emissions & Occupational health and safety \\
\hline & $\begin{array}{c}\text { Risk management } \\
\text { risks opportunities }\end{array}$ & Biodiversity and education & Human rights \\
\hline & Compliance & Community involvement \\
\hline
\end{tabular}


A company can be deemed as having sustainability communication if there is a compiled and published report, in other words, substantial information disclosed, for at least one of Environmental and Social aspects on top of having reported on Governance or Economic aspects. Simple descriptions will not be considered as substantial disclosure, and all the information needs to be publicly available. Providing that the company has communicated sustainability, we will evaluate each of the four indicators of the company and then come up with a total score, which is the sustainability reporting score. For the companies that have no disclosure on sustainability, they score zero. For the ones that have, we assign a score from 1 to 5 for each criterion and then convert to the score of that indicator with equal weighting so that each indicator has a maximum score of 25 . Subsequently, the sum of the four indicators will generate the total score, which ranges from 20 to 100.

\subsection{Firm Status}

In this paper, a company is defined as a government-lined company (GLC) if a substantial holding of at least $20 \%$ is held by the government-owned wealth fund, Temasek Holdings. The threshold is also used by Feng, Sun, and Tong [39] and Ang and Ding [40], when they examined the performance of GLCs in Singapore.

Meanwhile, we define firms where founders/co-founders or the family members are present among the 20 largest shareholders or as board members as family businesses [41].

\subsection{High-Impact Sector}

In order to investigate the impact of high-impact sector companies in our analysis, we use the high-impact sectors defined by SGX in the Guide to Sustainability Reporting. Ten high-impact sectors are defined. Details are provided in the empirical analysis section.

\subsection{Methodology}

In this paper, we employed the Ohlson [42] model as the baseline model, which is also used by $\mathrm{Xu}$, Magnan, and Andre [43], and Berthelot et al. [2]. The model is expressed as:

$$
M V_{i, t+4}=\alpha_{0}+\alpha_{1} B V_{i, t}+\alpha_{2} E A R N_{i, t}+\alpha_{3} E A R N_{i, t} \times N E G_{i, t}+\varepsilon_{i, t}
$$

where:

$M V_{i, t+4}$ is market value four months after financial year-end of company $i$;

$B V_{i, t}$ is book value of common equity at the year-end of company $i$;

$E A R N_{i, t}$ is earnings before extraordinary items at the year-end of company $i$;

$N E G_{i, t}$ is a dummy variable equal to 1 if earnings at the year-end of company $i$ are negative in year $t$ and 0 otherwise;

$\varepsilon_{i, t}$ is the error term.

Then, we included the sustainability score dummy variable to examine the relationship between sustainability communication and firm value to examine the $H_{1}$ hypothesis. Therefore, we have Model (2) as follows:

$$
M V_{i, t+4}=\alpha_{0}+\alpha_{1} B V_{i, t}+\alpha_{2} E A R N_{i, t}+\alpha_{3} E A R N_{i, t} \times N E G_{i, t}+\alpha_{4} S R_{i, t}+\varepsilon_{i, t}
$$

where the additional variable $S R_{i, t}$ is a dummy variable equal to 1 if the company $i$ is deemed as communicating sustainability for the year covered and 0 , otherwise.

Usually, the annual reports and sustainability reports are released in about three to four months after firms' financial year-end. Therefore, we use the market value four months after the financial year-end. According to prior literature, we expect the book value of common equity $\left(B V_{i, t}\right)$ and earnings $\left(E A R N_{i, t}\right)$ to be positively related to the market value, and the coefficient of the cross term with dummy variable $N E G_{i, t}$ to be negative as deficit is considered as a negative influence on the stock 
price. Furthermore, the sustainability reporting dummy variable $S R_{i, t}$ is supposed to be positively related to the market value.

As we cover listed companies in Singapore, we use weighted least squares (WLS) regression with the weight equal to the inverse of the square of stock market value, in order to resolve the scale effect [43].

After examining the relationship between having sustainability reporting or not and the firm value, we further investigate the relationship between the quality of sustainability reporting and market value to test the $H_{2}$ hypothesis. Thus, we replace the dummy variable $S R_{i, t}$ in Model (2) with the sustainability score $S R I_{i, t}$ and have the following Model (3):

$$
M V_{i, t+4}=\alpha_{0}+\alpha_{1} B V_{i, t}+\alpha_{2} E A R N_{i, t}+\alpha_{3} E A R N_{i, t} \times N E G_{i, t}+\alpha_{4} S R I_{i, t}+\varepsilon_{i, t},
$$

where $S R I_{i, t}$ is the sustainability reporting score of the company $i$.

Similarly, if the coefficient is significant, it is expected to be positive.

In addition, according to Reddy and Gordon [44], a statistically significant relationship between sustainability reporting and market returns is found for Australian companies, but not for New Zealand companies. As such, they proposed that the relationship between sustainability reporting and market returns is very much influenced by several contextual factors as well. Some factors include the industry that companies are operating within. Therefore, next, we will examine whether the relationships are driven by firm status or high impact sector. To be more specific, we add three control variables, government-linked companies $\left(G L C_{i, t}\right)$, family business $\left(F B_{i, t}\right)$ and high impact sector $\left(H I_{i, t}\right)$, one by one, in Models (2) and (3) and thus we have six additional models, Model (4) to Model (9), respectively. These models employ additional variables as follows: $G L C_{i, t}$ is a dummy variable equal to 1 if the company $i$ is a government-linked company and 0 otherwise; $F B_{i, t}$ is a dummy variable equal to 1 if the company $i$ is a family business and 0 otherwise; $H I_{i, t}$ is a dummy variable equal to 1 if the company $i$ is operated within the high impact sectors defined by SGX and 0 otherwise.

Assuming that the coefficients for the sustainability variables are significant, if the coefficients of the control variables are significant, the impact of the sustainability reporting is then partially attributed to the firm status or high impact sector, and, if neither is significant, it is safe to conclude that the relationship of sustainability reporting and firm's market value is strong and not driven by firm status or high impact sector.

\section{Results and Analysis}

\subsection{Descriptive Statistics}

Table 2 summarizes the descriptive statistics of all variables included in this study.

Table 2. Summary statistics of variables.

\begin{tabular}{ccccc}
\hline & Mean & Std. Dev. & Min & Max \\
\hline$M V_{i, t+4}$ & 767,187 & $3,251,133$ & 1203 & $4.57 \times 10^{7}$ \\
$B V_{i, t}$ & 680,697 & $2,594,333$ & $-46,114$ & $3.03 \times 10^{7}$ \\
$E A R N_{i, t}$ & 56,432 & 309,500 & $-716,450$ & $4,269,607$ \\
$N E G_{i, t}$ & 0.392 & 0.489 & 0 & 1 \\
$S R_{i, t}$ & 0.373 & 0.484 & 0 & 1 \\
$S R I_{i, t}$ & 16.280 & 21.884 & 0 & 78.776 \\
$G L C_{i, t}$ & 0.032 & 0.177 & 0 & 1 \\
$F B_{i, t}$ & 0.560 & 0.497 & 0 & 1 \\
$H I_{i, t}$ & 0.247 & 0.432 & 0 & 1 \\
\hline
\end{tabular}




\subsubsection{Sustainability Reporting and Firm Status}

In total, out of the 502 companies, 186 have communicated sustainability, or equivalently $37.1 \%$ of the companies. In addition, 16 of them are GLCs, all of which have disclosed sustainability related information. Furthermore, there are 279 family firms in the study, constituting $55.6 \%$ of all the mainboard-listed companies. Among these firms, 92 (33.0\%) communicated sustainability (Table 3).

Table 3. Sustainability communication by firm status.

\begin{tabular}{cccc}
\hline & $\begin{array}{c}\text { Number of Companies with } \\
\text { Sustainability Reporting }\end{array}$ & $\begin{array}{c}\text { Total Number of Companies } \\
\text { in the Category }\end{array}$ & $\begin{array}{c}\text { Percentage of Communication } \\
\text { in the Category }\end{array}$ \\
\hline Total & 186 & 502 & $37.1 \%$ \\
GLC & 16 & 16 & $100 \%$ \\
Family Business & 92 & 279 & $33.0 \%$ \\
\hline
\end{tabular}

Table 4 shows that, among the 186 companies that communicated sustainability, the average sustainability reporting score is 43.6. On average, GLCs perform better in terms of sustainability reporting as the average sustainability reporting score is 59.5, which is much higher than that of all 186 companies, 43.6 and that of family firms, 42.2. Although there are only 16 GLCs, the highest sustainability reporting score of all listed companies comes from GLC, while the company with the lowest score is a family business.

Table 4. Sustainability reporting score by firm status.

\begin{tabular}{cccc}
\hline & Min & Max & Average \\
\hline Total & 30.8 & 78.8 & 43.6 \\
GLC & 41.1 & 78.8 & 59.5 \\
Family Business & 30.8 & 73.4 & 42.2 \\
\hline
\end{tabular}

In general, public Singapore companies do not have much disclosure on sustainability as only about one-third of all mainboard listed companies have sustainability communication, and, for those companies that do communicate, the quality is yet to be improved as the average sustainability reporting score is below $50 \%$.

\subsubsection{High Impact Sector Analysis}

According to the Singapore Standard Industrial Classification (SSIC) 1996 information on SGX and the ten high impact sectors specified by SGX, 124 (24.7\%) out of the 502 companies are operating in the high impact sectors, among which, 39.5\% (49 companies) have sustainability reporting. The number of companies in each high impact sector and average score are summarized in Table 5.

Table 5. Companies communicating sustainability in high impact sector.

\begin{tabular}{|c|c|c|c|c|}
\hline Sector & $\begin{array}{c}\text { Number of } \\
\text { Companies within } \\
\text { the Sector }\end{array}$ & $\begin{array}{c}\text { Number of Companies } \\
\text { Communicating } \\
\text { Sustainability }\end{array}$ & $\begin{array}{l}\text { Percentage of } \\
\text { Communication } \\
\text { within the Sector }\end{array}$ & $\begin{array}{c}\text { Average } \\
\text { Sustainability } \\
\text { Reporting Score }\end{array}$ \\
\hline Agriculture & 7 & 7 & $100.0 \%$ & 38.7 \\
\hline Air Transport & 4 & 2 & $50.0 \%$ & 50.0 \\
\hline Chemicals \& Pharmeceuticals & 8 & 3 & $37.5 \%$ & 31.4 \\
\hline Construction & 32 & 13 & $40.6 \%$ & 14.5 \\
\hline Mining \& Metals & 24 & 3 & $12.5 \%$ & 17.6 \\
\hline Oil \& Gas & 10 & 4 & $40.0 \%$ & 35.3 \\
\hline Shipping & 8 & 2 & $25.0 \%$ & 17.6 \\
\hline Water & 3 & 1 & $33.3 \%$ & 64.7 \\
\hline Total & 124 & 49 & $39.5 \%$ & 31.5 \\
\hline
\end{tabular}


While the results are not conclusive due to small sub-sample sizes, it is interesting to note the indicative results. Some of the sectors have higher sustainability communication rates such as the Agriculture sector with all seven companies having sustainability reporting and Mining and Quarrying sector with a communication rate of $75.0 \%$. These two are also classified as high impact sectors that are encouraged to undertake sustainability reporting according to SGX. However, for other sectors, great efforts are yet to be made to improve the sustainability reporting. Among them, Manufacturing (23.9\%), Services (36.4\%) and Commerce (38.4\%) have the lowest disclosure rate (Table 6).

Table 6. Average sustainability reporting score by sector.

\begin{tabular}{cc}
\hline Sector & Average Sustainability Reporting Score \\
\hline Agriculture (AGR) & 46.0 \\
Commerce (COM) & 43.2 \\
Construction (CONS) & 38.6 \\
Finance (FIN) & 45.4 \\
Hotels/ Restaurants (HOTELS) & 41.4 \\
Manufacturing (MFG) & 43.0 \\
Mining \& Quarrying (MINQ) & 41.5 \\
Multi-Industry (MULTI) & 47.9 \\
Properties (PROP) & 42.5 \\
Services (SERV) & 44.4 \\
Transport, Storage \& Communications (TSC) & 45.5 \\
\hline
\end{tabular}

\subsection{Correlation Analysis}

We first examine the correlations between the variables. From Table 7, we can see that the correlations between book value, earnings before extraordinary items and market value are high (larger than 0.8 ). In addition, the two sustainability reporting variables relate to the market value with correlation coefficients higher than 0.2 .

Table 7. Correlation matrix of the variables.

\begin{tabular}{|c|c|c|c|c|c|c|}
\hline & $M V_{i, t+4}$ & $B V_{i, t}$ & $E A R N_{i, t}$ & $E A R N_{i, t} \times N E G_{i, t}$ & $S R_{i, t}$ & $S R I_{i, t}$ \\
\hline$M V_{i, t+4}$ & 1.0000 & & & & & \\
\hline$B V_{i, t}$ & $0.8183^{* * *}$ & 1.0000 & & & & \\
\hline$E A R N_{i, t}$ & $0.8078^{* * *}$ & $0.9210^{* * *}$ & 1.0000 & & & \\
\hline$E A R N_{i, t} \times N E G_{i, t}$ & 0.0074 & -0.0164 & $0.1783^{* * *}$ & 1.0000 & & \\
\hline$S R_{i, t}$ & $0.2562^{* * *}$ & $0.2610^{* * *}$ & $0.2107^{* * *}$ & -0.0540 & 1.0000 & \\
\hline$S R I_{i, t}$ & $0.3497^{* * *}$ & $0.3522 * * *$ & $0.2912 * * *$ & $-0.0790 *$ & $0.9644^{* * *}$ & 1.0000 \\
\hline
\end{tabular}

\subsection{Regression Results}

We start with running the regression of the base model. The next step is to add the dummy variable of sustainability reporting (the $H_{1}$ hypothesis) and the sustainability reporting score (the $\mathrm{H}_{2}$ hypothesis) variables, respectively. Table 8 summaries the results of the three models. According to the results, the base model stands and signs of the coefficients are as expected. In particular, the coefficients of both the dummy and the scale variables are significant and positive. In other words, whether the company has sustainability disclosure or not is positively related to the firm value and better quality is associated with higher market value. Thus, the results suggest that we should accept both hypotheses. 
Table 8. Regression results of base models and sustainability.

\begin{tabular}{ccccc}
\hline Variables & Expected Sign & Model (1) & Model (2) & Model (3) \\
\hline Constant & & $1714.30^{* * *}$ & $1546.39^{* * *}$ & $1547.20^{* * *}$ \\
$B V_{i, t}$ & $(+)$ & $0.13^{* * *}$ & $0.12^{* * *}$ & $0.12^{* * *}$ \\
$E A R N_{i, t}$ & $(+)$ & $0.81^{* * *}$ & $0.77^{* * *}$ & $0.77^{* * *}$ \\
$E A R N_{i, t} \times N E G_{i, t}$ & $(-)$ & $-0.74^{* * *}$ & $-0.71^{* * *}$ & $-0.71^{* * *}$ \\
$S R_{i, t}$ & $(+)$ & & $7911.68^{* * *}$ & \\
$S R I_{i, t}$ & $(+)$ & & & $203.94^{* * *}$ \\
$R^{2}$ & & 0.239 & 0.267 & 0.269 \\
Adjusted $R^{2}$ & & 0.235 & $0.261^{* * *}$ & 0.262 \\
F-value & & $50.42^{* * *}$ & $43.81^{* * *}$ & $44.04^{* * *}$ \\
\hline
\end{tabular}

Notes: ${ }^{* * *} p \leq 0.01 ;{ }^{*} p \leq 0.10$.

Then, we include the GLC, family business and high impact sector control variables and run the regression again. Results are shown in Table 9. With the control variables, coefficients of rest variables are still significant, but those of all three control variables are not significant, which suggests that statistically there is no relationship between firm status and its market value. Therefore, it reinforces the previous results regarding the link between sustainability reporting and firm value.

Table 9. Regression results including firm status variables.

\begin{tabular}{|c|c|c|c|c|c|c|}
\hline Variables & Model (4) & Model (5) & Model (6) & Model (7) & Model (8) & Model (9) \\
\hline Constant & $1551.15^{* * *}$ & $866.00^{* * *}$ & $1844.37^{* * *}$ & $1552.09^{* * *}$ & 889.81 & $1844.08^{* * *}$ \\
\hline$B V_{i, t}$ & $0.12^{* * *}$ & $0.13^{* * *}$ & $0.12^{* * *}$ & $0.12 * * *$ & $0.13^{* * *}$ & $0.12^{* * *}$ \\
\hline$E A R N_{i, t}$ & $0.77^{* * *}$ & $0.74^{* * *}$ & $0.82^{* * *}$ & $0.77^{* * *}$ & $0.74^{* * *}$ & $0.82^{* * *}$ \\
\hline$E A R N_{i, t} \times N E G_{i, t}$ & $-0.70^{* * *}$ & $-0.67^{* * *}$ & $-0.75^{* * *}$ & $-0.70^{* * *}$ & $-0.67^{* * *}$ & $-0.75^{* * *}$ \\
\hline$S R_{i, t}$ & $7850.81^{* * *}$ & $8016.22 * * *$ & $7921.38^{* * *}$ & & & \\
\hline$S R I_{i, t}$ & & & & $202.13^{* * *}$ & $205.77^{* * *}$ & $204.12^{* * *}$ \\
\hline$G L C_{i, t}$ & 94030.16 & & & 66572.53 & & \\
\hline$F B_{i, t}$ & & 1050.5 & & & 1015.53 & \\
\hline$H I_{i, t}$ & & & -1012.89 & & & -1008.93 \\
\hline$R^{2^{\prime \prime}}$ & 0.27 & 0.27 & 0.27 & 0.27 & 0.27 & 0.27 \\
\hline Adjusted $R^{2}$ & 0.26 & 0.26 & 0.26 & 0.26 & 0.26 & 0.26 \\
\hline F-value & $35.52^{* * *}$ & $35.54^{* * *}$ & $35.40 * * *$ & $35.69^{* * *}$ & $35.69^{* * *}$ & $35.58^{* * *}$ \\
\hline
\end{tabular}

\section{Conclusions}

In this paper, we examine the linkage between sustainability reporting and firm value in terms of market value, based on data of mainboard-listed companies in Singapore. With reference to the international standards and local regulations, we use a comprehensive framework to measure the sustainability reporting of firms. While existing studies show mixed conclusions of whether there is a linkage between sustainability and firm value, our results suggest that sustainability disclosure is positively related to the market value of a firm, and the better the quality of sustainability reporting, the stronger the linkage. In addition, we find that firm status such as government ownership, family business and operating in high impact sectors does not have impacts on the linkage.

Our contributions to existing literature are in three key domains.

First, for research, our study is a unique examination of the emerging phenomenon of sustainability reporting in Asia, particularly the business and finance hub of Singapore. The empirical results in the new context, compared with those in more matured economic settings, will inspire further investigations to be carried out, especially in the Asian region. New theoretical advancements may also be made subsequently when the results show novel twists in the institutional and cultural environments of Asia. 
Second, for practice, our study develops a better understanding on the measurements and implications of sustainability reporting drawing on practice tools that have become global standards such as the GRI. The results will encourage better awareness, acceptance and adoption of sustainability amongst companies, especially with the confidence that there are benefits in terms of market values.

Third, for policy, many governments in various countries, especially those in Asia, are currently looking into how to strengthen the regulatory approaches. As embodied in the challenges of introducing sustainability measures such as in the problems of externalities and free-riding, it will be good if there is empirical evidence on the merits of sustainability. Our study is probably the first of its kind in Asia that marries practical frameworks with rigorous econometric testing. Our results are interestingly positive. These may provide better assurances of validity for policy makers, even as they intensify sustainability regulations in the respective jurisdictions.

In terms of limitations, although our findings suggest a positive relationship between the firm value and sustainability reporting, future studies may be needed to explore the causality effects-whether it is having sustainability reporting or that better quality of sustainability reporting leads to larger market value or firms with larger market value tend to put more effort on the sustainability reporting. Beyond the standard econometric approach that we adopt, an alternative approach is to explicate the causality aspects from an economic experimental angle, along the line of Ciasullo, Maione, Torre and Troisi [45].

In addition, our paper refers to the GRI guidelines because they are widely recognized across the world, including Singapore. However, there are other established international reporting guidelines such as the IR framework, which highlights the importance of including business model in the reporting. In the future, when more companies follow the IR guidelines, a wider spectrum of business variables may then be involved in the study.

Acknowledgments: Part of this study is funded by the Musim Mas Research Grant provided through the NUS Business School at National University of Singapore.

Author Contributions: Lawrence Loh and Wang Yu conceptualized the study; Lawrence Loh and Thomas Thomas conceived and designed the assessment framework; Wang Yu managed the data collection initiatives; Lawrence Loh and Wang Yu conducted the empirical analysis; Lawrence Loh, Thomas Thomas and Wang Yu documented the findings.

Conflicts of Interest: The authors declare no conflict of interest.

\section{References}

1. Singapore Exchange. Sustainability Reporting Guide; Working Paper. 2016. Available online: http://rulebook.sgx.com/net_file_store/new_rulebooks/s/g/SGX_Mainboard_Practice_Note_7.6_July_ 20_2016.pdf (accessed on 2 September 2017).

2. Berthelot, S.; Coulmont, M.; Serret, V. Do investors value sustainability reports? A Canadian study. Corp. Soc. Responsib. Environ. Manag. 2012, 19, 355-363. [CrossRef]

3. Khaveh, A.; Nikhasemi, S.R.; Haque, A.; Yousefi, A. Voluntary sustainability disclosure, revenue, and shareholders wealth-a perspective from Singaporean companies. Bus. Manag. Dyn. 2012, 1, 6-12.

4. Brown, H.S.; de Jong, M.; Levy, D.L. Building institutions based on information disclosure: Lessons from GRI's sustainability reporting. J. Clean. Prod. 2009, 17, 571-580. [CrossRef]

5. Watts, S. Corporate social responsibility reporting platforms: Enabling transparency for accountability. Inf. Technol. Manag. 2015, 16, 19-35. [CrossRef]

6. Ioannou, I.; Serafeim, G. The Consequences of Mandatory Corporate Sustainability Reporting: Evidence from Four Countries; Harvard Business School: Boston, MA, USA, 2016.

7. Herremans, I.M.; Akathaporn, P.; McInnes, M. An investigation of corporate social responsibility reputation and economic performance. Account. Organ. Soc. 1993, 18, 587-604. [CrossRef]

8. Simpson, W.G.; Kohers, T. The link between corporate social and financial performance: Evidence from the banking industry. J. Bus. Ethics 2002, 35, 97-109. [CrossRef]

9. Orlitzky, M.; Schmidt, F.L.; Rynes, S.L. Corporate social and financial performance: A meta-analysis. Organ. Stud. 2003, 24, 403-441. [CrossRef] 
10. Clark, T.; Allen, D. Shareholder value from sustainability leadership: Comparing valuation ratios within industry groups. Int. J. Financ. Econ. 2012, 89, 108-117.

11. Ameer, R.; Othman, R. Sustainability practices and corporate financial performance: A study based on the top global corporations. J. Bus. Ethics 2012, 108, 61-79. [CrossRef]

12. Murray, A.; Sinclair, D.; Power, D.; Gray, R. Do financial markets care about social and environmental disclosure? Further evidence and exploration from the UK. Account. Audit. Account. J. 2006, 19, 228-255. [CrossRef]

13. López, M.V.; Garcia, A.; Rodriguez, L. Sustainable development and corporate performance: A study based on the Dow Jones sustainability index. J. Bus. Ethics 2007, 75, 285-300. [CrossRef]

14. Cormier, D.; Magnan, M. The revisited contribution of environmental reporting to investors' valuation of a firm's earnings: An international perspective. Ecol. Econ. 2007, 62, 613-626. [CrossRef]

15. Guidry, R.; Patten, D. Market Reactions to the First-Time Issuance of Corporate Sustainability Reports: Evidence that Quality Matters. Sustain. Account. Manag. Policy J. 2010, 1, 33-50. [CrossRef]

16. Carnevale, C.; Mazzuca, M.; Venturini, S. Corporate social reporting in European Banks: The effects on a firm's market value. Corp. Soc. Responsib. Environ. Manag. 2012, 19, 159-177. [CrossRef]

17. García-Benau, M.A.; Sierra-Garcia, L.; Zorio, A. Financial crisis impact on sustainability reporting. Manag. Decis. 2013, 51, 1528-1542. [CrossRef]

18. Branco, M.C.; Rodrigues, L.L. Factors influencing social responsibility disclosure by Portuguese companies. J. Bus. Ethics 2008, 83, 685-701. [CrossRef]

19. Souto, B.F.F. Crisis and corporate social responsibility: Threat or opportunity? Int. J. Econ. Sci. Appl. Res. 2009, 2, 36-50.

20. Cormier, D.; Magnan, M.; Van Velthoven, B. Environmental disclosure quality in large German companies: Economic incentives, public pressures or institutional conditions? Eur. Account. Rev. 2005, 14, 3-39. [CrossRef]

21. Tagesson, T.; Blank, V.; Broberg, P.; Collin, S.O. What explains the extent and content of social and environmental disclosures on corporate websites: A study of social and environmental reporting in Swedish listed corporations. Corp. Soc. Responsib. Environ. Manag. 2009, 16, 352-364. [CrossRef]

22. Galani, D.; Gravas, E.; Stavropoulos, A. Company characteristics and environmental policy. Bus. Strategy Environ. 2012, 21, 236-247. [CrossRef]

23. Clarkson, P.M.; Li, Y.; Richardson, G.D.; Vasvari, F.P. Revisiting the relation between environmental performance and environmental disclosure: An empirical analysis. Account. Organ. Soc. 2008, 33, 303-327. [CrossRef]

24. Bakar, A.; Sheikh, A.; Ameer, R. Readability of corporate social responsibility communication in Malaysia. Corp. Soc. Responsib. Environ. Manag. 2011, 18, 50-60. [CrossRef]

25. Gray, R.; Kouhy, R.; Lavers, S. Corporate social and environmental reporting: A review of the literature and a longitudinal study of UK disclosure. Account. Audit. Account. J. 1995, 8, 47-77. [CrossRef]

26. Hooghiemstra, R. Corporate communication and impression management-New perspectives why companies engage in corporate social reporting. J. Bus. Ethics 2000, 27, 55-68. [CrossRef]

27. Ortas, E.; Gallego-Alvarez, I.; Álvarez Etxeberria, I. Financial factors influencing the quality of Corporate Social Responsibility and Environmental Management disclosure: A quantile regression approach. Corp. Soc. Responsib. Environ. Manag. 2015, 22, 362-380. [CrossRef]

28. Clarkson, P.M.; Fang, X.; Li, Y.; Richardson, G. The relevance of environmental disclosures: Are such disclosures incrementally informative? J. Account. Public Policy 2013, 32, 410-431. [CrossRef]

29. Malik, M. Value-enhancing capabilities of CSR: A brief review of contemporary literature. J. Bus. Ethics 2015, 127, 419-438. [CrossRef]

30. Reverte, C. Corporate social responsibility disclosure and market valuation: Evidence from Spanish listed firms. Rev. Manag. Sci. 2016, 10, 411-435. [CrossRef]

31. Verbeeten, F.H.; Gamerschlag, R.; Möller, K. Are CSR disclosures relevant for investors? Empirical evidence from Germany. Manag. Decis. 2016, 54, 1359-1382. [CrossRef]

32. Kim, O.; Verrecchia, R.E. Market liquidity and volume around earnings announcements. J. Account. Econ. 1994, 17, 41-67. [CrossRef]

33. Healy, P.M.; Hutton, A.P.; Palepu, K.G. Stock performance and intermediation changes surrounding sustained increases in disclosure. Contemp. Account. Res. 1999, 16, 485-520. [CrossRef] 
34. Richardson, A.J.; Welker, M. Social disclosure, financial disclosure and the cost of equity capital. Account. Organ. Soc. 2001, 26, 597-616. [CrossRef]

35. Datar, S.M.; Feltham, G.A.; Hughes, J.S. The role of audits and audit quality in valuing new issues. J. Account. Econ. 1991, 14, 3-49. [CrossRef]

36. Feltham, G.A.; Hughes, J.S.; Simunic, D.A. Empirical assessment of the impact of auditor quality on the valuation of new issues. J. Account. Econ. 1991, 14, 375-399. [CrossRef]

37. Loh, L.; Low, B.; Sim, I.; Thomas, T. Accountability for a Sustainable Future: Sustainability Reporting in Singapore among Singapore Exchange Mainboard Listed Companies 2013. Working Paper. 2014. Available online: http://www.csrsingapore.org/c/images/stories/publications/FA_Singapore\% 20Compact\%20Research\%20Study\%20Publication_290714.pdf (accessed on 10 May 2017).

38. Loh, L.; Nguyen, T.; Sim, I.; Thomas, T.; Wang, Y. Sustainability Reporting in Singapore: The State of Practice among Singapore Exchange (SGX) Mainboard Listed Companies 2015. Working Paper. 2016. Available online: http:/ /bschool.nus.edu.sg/eflyer/2016/cgio/sustainability-report-roundtable/docs/acncgio-singapore-report-oct2016.pdf (accessed on 10 May 2017).

39. Feng, F.; Sun, Q.; Tong, W.H. Do government-linked companies underperform? J. Bank. Financ. 2004, 28, 2461-2492. [CrossRef]

40. Ang, J.S.; Ding, D.K. Government ownership and the performance of government-linked companies: The case of Singapore. J. Multinatl. Financ. Manag. 2006, 16, 64-88. [CrossRef]

41. Dieleman, M.; Shim, J.; Muhammad, I. Asian Family Firms: Success and Succession. Working Paper. 2013. Available online: http://bschool.nus.edu/Portals/0/images/CGIO/Report/Asian\%20Family\% 20Business\%20Report.pdf accessed on 10 May 2017).

42. Ohlson, J.A. Earnings, book values, and dividends in equity valuation. Contemp. Account. Res. 1995, 11, 661-687. [CrossRef]

43. Xu, B.; Magnan, M.L.; Andre, P.E. The stock market valuation of R\&D information in biotech firms. Contemp. Account. Res. 2007, 24, 1291-1318.

44. Reddy, K.; Gordon, L.W. The effect of sustainability reporting on financial performance: An empirical study using listed companies. J. Asia Entrepreneur. Sustain. 2010, 6, 19-42.

45. Ciasullo, M.V.; Maione, G.; Torre, C.; Troisi, O. What about Sustainability? An Empirical Analysis of Consumers' Purchasing Behavior in Fashion Context. Sustainability 2017, 9, 1617. [CrossRef] 